\title{
Administrators' bread: an experiment-based re-assessment of the functional and cultural role of the Uruk bevel-rim bowl
}

Jill Goulder*

Well-designed experimental archaeology combined with ingenious social argument show that a type of coarse-ware pottery, the BRB, performed a key role in early Mesopotamian governance. Its thick walls and conical shape produce a fine loaf of risen bread, supplied perhaps as tasty recompense to those undertaking the newly-proliferating public administrative duties.

Keywords: Uruk, bevel-rim bowl, BRB, bread

\section{The significance of BRBs in the Uruk period}

Bevel-rim bowls (BRBs) are distinctive coarse, thick-walled, conical ceramic bowls that first appear in southern Mesopotamia in the early fourth millennium (Table 1), and by the mid-fourth millennium cluster in their thousands throughout Mesopotamia and the surrounding regions, declining to extinction by $3000 \mathrm{BC}$ (except in some peripheral areas of Mesopotamian influence to the north-west). Their trajectory coincides with the Uruk period, one of unprecedented urbanisation and bureaucratic control culminating in the introduction of writing. A better understanding of the function and significance of BRBs could materially assist commentators by shedding light on the extent and nature of central control, distribution and bureaucracy in the late Uruk period, as well as on the dietary and other habits which formed part of the unique and pervasive Uruk culture.

While experimental manufacture and usage of replica artefacts should never form the sole basis for interpretation of past practices, it can assist in reducing the options. My aim in this experimental study was to assist in clearing away some of the accreted assumptions that so often dog discussion of key material tracers such as the BRB.

\section{Manufacturing BRBs}

Examination of the $\mathrm{BRB}$ manufacturing process has been an underemployed tool for ascertaining drivers for the development of the primary 'BRB system'. BRB fabric features heavy organic temper and probably local clay (see below); the vessels are low-fired and

* Institute of Archaeology, University College London, 31-34 Gordon Square, London WC1H OPY, UK (Email: jill@jgoulder.com) 
Table 1. Approximate BRB timeline (Adams 1972: 99-100; Wright 1981: 125 \& 165; Potts 1984: 262-3; Nicholas 1987: 62 \& 65; Millard 1988: 54; Oates 1993: 415; Badler 1995: 54; Pollock \& Coursey 1996: 234; Tomita 1998: 199; Collins 2000: 26; Schwartz 2001; Wright \& Rupley 2001: 93 \& 120; Frangipane 2002: 126; Rothman 2002: 55).

\begin{tabular}{|c|c|c|c|c|}
\hline $\mathrm{BC}(\mathrm{cal})$ & Period & S Mesopotamia & N Mesopotamia & Iran \\
\hline (4400) 4200-3900 & Late Ubaid & $\begin{array}{l}\text { Coarse } \\
\text { flint-scraped } \\
\text { bowls }\end{array}$ & $\begin{array}{l}\text { Wide flowerpots } \\
\text { (slow wheel), coarse } \\
\text { flint-scraped bowls }\end{array}$ & $\begin{array}{l}\text { Coarse flint-scraped } \\
\text { bowls }\end{array}$ \\
\hline $3900-3600$ & Early Uruk & $\begin{array}{l}\text { BRBs appear } c \text {. } \\
\quad 3900\end{array}$ & $\begin{array}{l}\text { Wide flowerpots } \\
\text { cease; Coba bowls, } \\
\text { other non-bevelled } \\
\text { coarse bowls e.g. } \\
\text { Arslantepe; a few } \\
\text { BRBs - Brak, } \\
\text { Nineveh, Amuq }\end{array}$ & $\begin{array}{l}\text { Coarse flint-scraped } \\
\text { bowls }\end{array}$ \\
\hline $3600-3400$ & Mid Uruk & $\begin{array}{l}\text { BRBs common } \\
\text { Conical cups }\end{array}$ & $\begin{array}{l}\text { BRBs common by } \\
\mathbf{3 6 0 0} \\
\text { Conical cups \# }\end{array}$ & $\begin{array}{l}\text { BRBs common at } \\
\text { some sites by } \\
3600 \\
\text { Conical cups \# }\end{array}$ \\
\hline $3400-3200$ & Late Uruk & & & \\
\hline $3200-3100$ & Jemdet Nasr & $\begin{array}{l}\text { BRBs decline Tall } \\
\text { flower-pots } \\
\text { increase; conical } \\
\text { cups (including } \\
\text { solid-footed } \\
\text { goblets) increase }\end{array}$ & $\begin{array}{l}\text { BRBs continue Tall } \\
\text { flower-pots, conical } \\
\text { cups increase }\end{array}$ & $\begin{array}{l}\text { BRBs decline Tall } \\
\text { flower-pots } \\
\text { increase; conical } \\
\text { cups (including } \\
\text { solid-footed } \\
\text { goblets) increase }\end{array}$ \\
\hline $3100-2900$ & ED1 & $\begin{array}{l}\text { Solid-footed } \\
\text { goblets }\end{array}$ & $\begin{array}{l}\text { BRBs cease by } 3000 \\
\text { except a few in } \\
\text { Syro-Anatolia }\end{array}$ & Solid-footed goblets \\
\hline
\end{tabular}

\# Contemporary with BRBs at e.g. Godin Tepe, Şarafabad, Hacınebi

typically show no burnt cores or exterior blackening. I manufactured a total of $28 \mathrm{BRBs}$, using London clay, chopped hay, dung and sand, and had them fired commercially at $600^{\circ} \mathrm{C}$ and $700^{\circ} \mathrm{C}$, producing convincing replicas (Figure 1).

Kalsbeek (1980) takes the fingermarks often found on the exteriors of BRBs to indicate hand-making, but I found from experiment that the fingermarks better reflect manipulation during moulding, and that considerable effort is required to achieve the distinctive straight sides and flat base by hand-making. The majority of commentators agree that BRBs were mould-made, citing the typical crinkled exterior and smooth interior surfaces, the 'frill' of the clay spilling over the mould edge, and the fistmarks inside (Le Brun 1980: 60; Nicholas 1987: 62; McAdam \& Mynors 1988: 40). Opinion is divided on whether moulding was in the ground (e.g. Johnson 1973: 130; Beale 1978: 289; Strommenger 1980: 58; Miller 1981: 128) or in a freestanding wooden or other mould (e.g. Adams 1972: 99; Balfet 1980: 78; Forest 1987: 3; Charvát 2002: 124; Crawford 2004: 164).

Henry Wright (pers. comm. 2007) has successfully manufactured BRBs through groundmoulding. I experimented with this method, but found that initial forming of the straight 


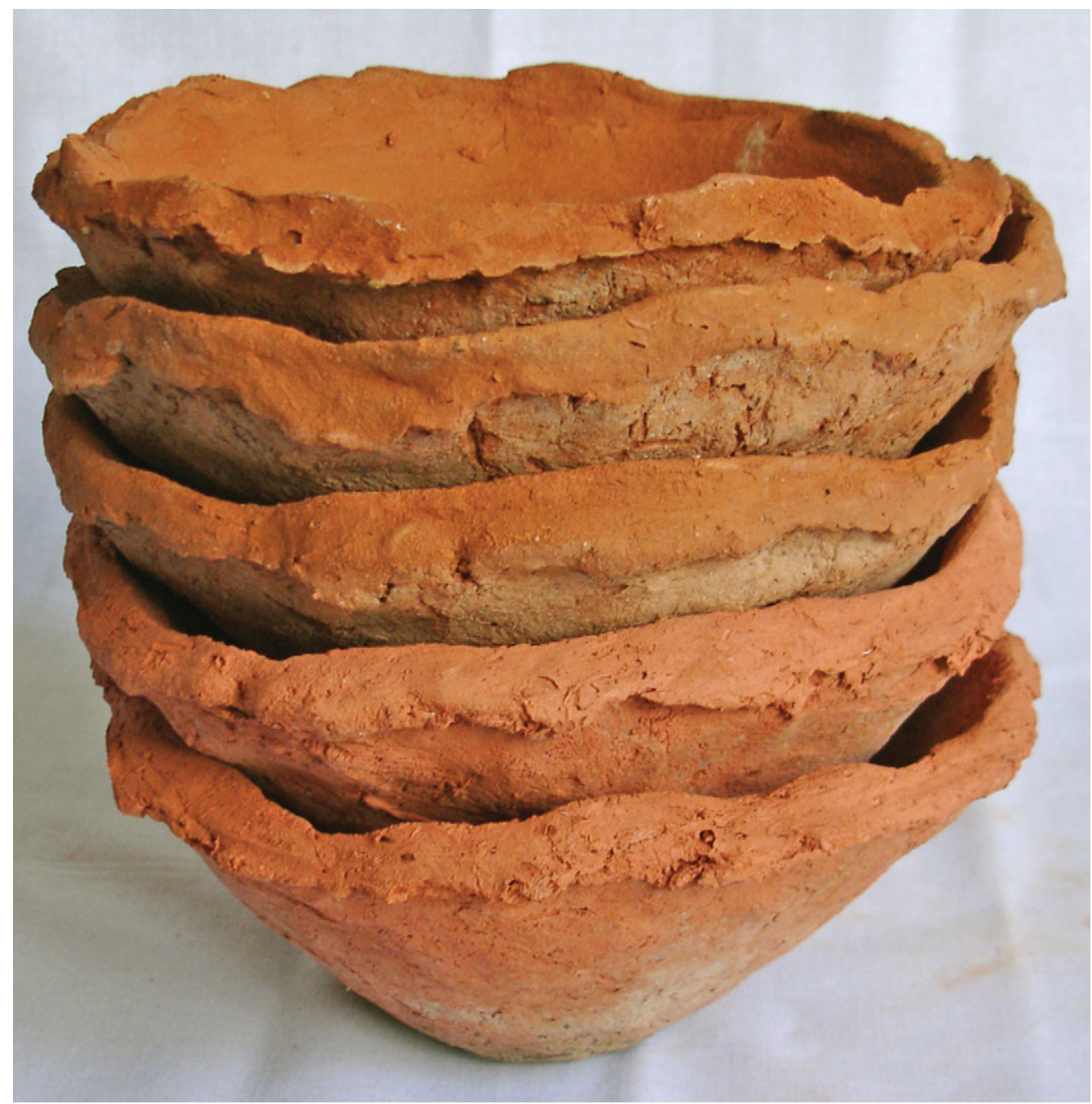

Figure 1. Replica BRBs made in a BRB.

sides and flat base of a ground-mould is tricky and time-consuming, even using an existing $\mathrm{BRB}$ as employed by Wright, and that a free-standing mould was more convenient for initial smoothing and for bevelling of the rim. Undoubtedly BRBs could be made in the ground, but ground-moulding on a mass scale would be profligate of space and inflexible; in a freestanding mould the clay dries more quickly, freeing the mould for immediate re-use (see Table 2).

Bill Sillar's suggestion (pers. comm. 2007) of an existing BRB as a mould proved strikingly successful in my experiments, the straight flare of the sides and well-defined inner base corners producing 'clones' of very similar dimensions, with the clay rising above the mould walls and falling naturally into the 'frill' or flange typical of BRBs. The ridged inner mould-base obviated sticking, and the heavily-tempered bowls did not shrink during firing. 
Administrators' bread

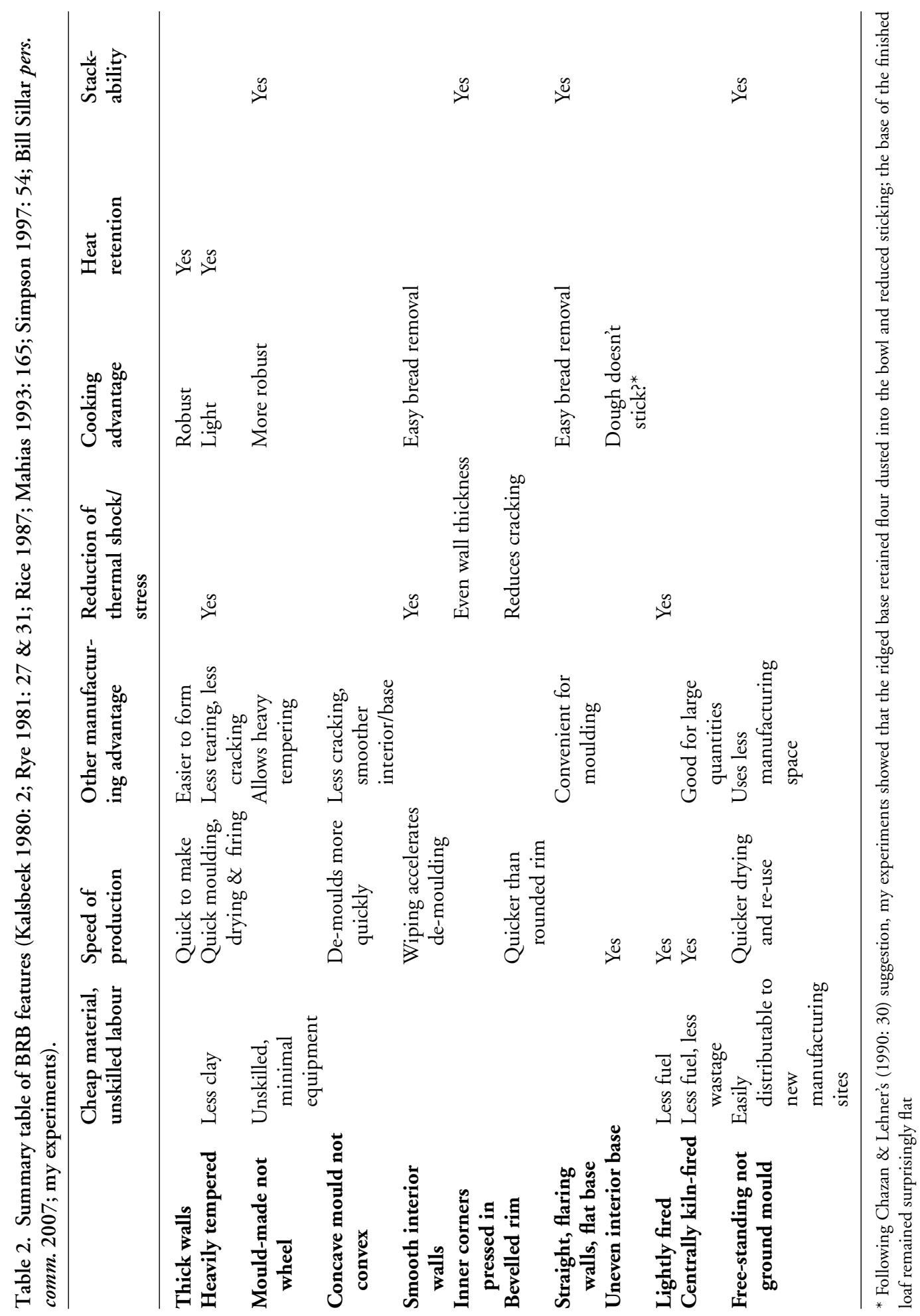


Why was wheel-throwing not used? The date of the emergence of the fast wheel is debated, but wheel-throwing is not necessarily quicker: a wheel-led production line can only move at the speed of the expert potter, whereas all stages of mould manufacture can be carried out by unskilled workers (Nissen 1988: 90 and my experiment). The heavy temper required for BRBs to function well in use would militate against successful wheel-throwing, and stackable uniformity is more simply achievable with moulds.

The virtue of the BRB concept is that it is easily mass-produceable but so simple in design that small ad hoc needs can also be fulfilled individually, by non-potters, with no tools other than an existing BRB. The elegant concept of a BRB as a mould for a BRB has the additional advantage of allowing very simple transmission of the BRB manufacturing instructions for a vessel not well-adapted for mass transportation: a single BRB could be conveyed to a new location. Very little work has been done on BRB clay origins, but local clay is reported at Tell Brak, Tell Rubeidheh and Jerablus Tahtani (McAdam \& Mynors 1988: 39; Stephen \& Peltenburg 2002: 178; Joan Oates pers. comm. 2007).

\section{The original ration theory and the concept of bread-baking in BRBs}

Written evidence for the existence of centrally-organised Mesopotamian systems of food distribution to work-gangs in the latter half of the third millennium was a key inspiration for the argument by Nissen, Johnson and others for BRBs as size-specific containers for grain-rations in the fourth-millennium Uruk. This was challenged by Beale (1978), Miller (1981: 128), Sürenhagen (1974/5: 73) and others who found a wide range of BRB volumes with little or no clustering, and who also questioned a system involving giving away an awkward, heavy container to the ration recipient daily - not least because BRBs are so much more likely to be found centrally than accumulated in private homes.

Additionally, the concept of BRBs as ration-bowls for work-gangs is increasingly seen as fitting ill with more recent discoveries of small quantities of BRBs (see below). The baking of leavened bread in BRBs for work-gang rations was advanced as an alternative to grain distribution by Baumgärtel (1947: 93) and later by Schmidt (1982: 317), Millard (1988) and Chazan \& Lehner (1990), not least because finished loaf volume is little affected by minor variations in container volume: in Egypt, in a system devised by scribes rather than potters or bakers, bread output was simply measured by grain volume input (Kemp 2006: 174). The original inspiration for the 'BRB bread' theory was indeed a visual parallel with later Egyptian bread-moulds, and there are significant contextual similarities (see Table 3 for culinary associations), but Joffe (1998: 299), Schmidt and others take the view that Mesopotamian and Egyptian bread-making practices are parallel developments - an equifinality resulting from bread-making practicalities.

\section{Experimental assessment of some suggested functions}

While support for the theory of BRBs as bread-moulds is now fairly widespread, other functions have also been suggested. Any discussion of function should be prefaced with the observation that the wide variety of BRB contexts can probably only be explained by the acceptance that BRBs, as easily-made and useful vessels, drifted away from their primary 
Table 3. Contexts of large BRB concentrations (where known).

\begin{tabular}{|c|c|c|c|}
\hline Site & $\begin{array}{l}\text { Deposition } \\
\text { (see key) }\end{array}$ & (Association see key) & Source \\
\hline Abu Salabikh & & $\boldsymbol{\nabla}(\mathbf{\nabla} ?)$ & $\begin{array}{l}\text { (Pollock et al. 1996: 689; Wright \& } \\
\text { Rupley 2001: 93) }\end{array}$ \\
\hline Chogha Mish & $\Delta$ & $\bullet$ & (Delougaz \& Kantor 1996: $31 \& 97$ ) \\
\hline Eridu & - & $\boldsymbol{\nabla} \nabla$ & (Beale 1978: 303) \\
\hline Farukhabad & & $\boldsymbol{\nabla} \nabla$ & (Wright 1981: 186) \\
\hline Godin Tepe & - & $\nabla$ & (Badler 1995: 54) \\
\hline Habuba Kabira & - & $\nabla \nabla$ & $\begin{array}{l}\text { (Forest 1987: 19; Chazan \& Lehner } \\
\text { 1990: 30) }\end{array}$ \\
\hline Hacınebi & - & $\bullet$ & (Stein \& Misır 1996: 234) \\
\hline Hamoukar & & & (Miranda Semple pers. comm. 2008) \\
\hline Jebel Aruda & - & $\boldsymbol{\nabla} \nabla$ & $\begin{array}{l}\text { (Chazan \& Lehner 1990: 30; } \\
\text { Frangipane 2001: 312) }\end{array}$ \\
\hline KS-54, Susiana & & $\boldsymbol{\nabla}$ & (Johnson 1976: 208-9) \\
\hline Khafaje & & & (Delougaz 1952: 128) \\
\hline Nineveh & $\Delta$ & $(\boldsymbol{\nabla} ?)$ & $\begin{array}{l}\text { (Mallowan 1933: 168; Le Brun } \\
\text { 1980: 62) }\end{array}$ \\
\hline Qraya & $\Delta$ & $\nabla \nabla$ & (Buccellati 1999: 233) \\
\hline Şarafabad & $\Delta$ & $\nabla$ & $\begin{array}{l}\text { (Wright 1998: 181; Wright et al. } \\
\text { 1980: 271) }\end{array}$ \\
\hline Susa & $\Delta$ & $\bullet$ & (Schmandt-Besserat 1992: 116) \\
\hline Tal-e Malyan & - & $\nabla \nabla$ & (Nicholas 1987: 65-8) \\
\hline Tell Brak & $\Delta$ & $\nabla \nabla$ & (Joan Oates pers. comm. 2008) \\
\hline Tell Hajib & & & (Schwartz 2001: 251) \\
\hline Tell Rubeidheh & - & $\bullet$ & (McAdam \& Mynors 1988: 39) \\
\hline Telloh & $\Delta$ & & (Le Brun 1980: 62) \\
\hline Umm Qseir & & & (Tomita 1998: 146) \\
\hline Uqair & & $\bullet$ & (Beale 1978: 303) \\
\hline Ur & & $\bullet$ & (Beale 1978: 306) \\
\hline Uruk & $\Delta$ & $\bullet$ & (Beale 1978: 303) \\
\hline
\end{tabular}

\ Deposition apparently a single dump (excluding kiln/oven finds)

- Apparently accumulated deposition over time

- Found in association with administrative buildings or craft activity areas

v Associated with kitchen refuse/ash

$\boldsymbol{\nabla}$ Associated with oven

activity into a range of roles (for example, holding melted bitumen at Hacınebi and Jerablus Tahtani (Peltenburg et al. 1996: 3; Stein \& Misır 1996: 216)). If, as I argue later, BRB-need rose and fell at some sites, the unneeded bowls might well have been thriftily recycled. It remains important, though, not to lean on secondary use as an explanation for anything in the record that fails to fit an argument. Likewise it is important not to contort every BRB find to suit a primary-use theory. 
In my experimental study, I tested some of the main functional theories advanced - bread (discussed later), yoghurt, cheese and salt manufacture. I briefly report the findings here. The theory that BRBs were used for yoghurt or soft cheese manufacture may stem from an initial suggestion by Delougaz (1952: 128) about 'the separation of curds and whey', expanded into an ethnographic anecdote in Delougaz \& Kantor (1996: 50) concerning women in Iran making yoghurt or cheese in bowls of similar appearance. In my experiment, I successfully produced yoghurt but it proved very difficult to pour or spoon out of the rough $\mathrm{BRB}$, while in my cheese-making experiments with milk and curdling agents the whey did not drain at all, and two of the four BRBs used became fragile and crumbled. Buccellati's (1999: 233-4) suggestion that BRBs were used in salt purification hinges on the concentrated numbers found in association with other Uruk material culture at the small, non-urban eastern Syrian site of Qraya. In a brief experiment with wet salt precipitated from brine, the salt dried out well as the water soaked into the bowl, but then had to be scraped out with difficulty, with the damp BRB again breaking when picked up.

More successfully, I experimentally baked a total of 10 leavened loaves in replica BRBs (Figure 2), setting myself the task of producing a well-risen, palatable loaf by as simple and speedy a process as possible. In terms of the flour used, my experiments with emmer wheat and barley confirmed professional bakers' views that despite the low levels of true gluten in emmer wheat, emmer bread has the potential to rise much more than barley, resulting in more loaf per volume of flour. This is something which may have been desirable for bureaucrats measuring output volume rather than calorific value. The much cheaper and more widespread barley (Oates \& Oates 1976: 116; Potts 1997: 59; Algaze 2001: 212) therefore benefits little from a preheated container, though, as with wheat, the texture and taste is improved (Samuel 2000: 545).

Briefly, my experiments indicated that:

- Preheating BRBs (a process suggested by Millard (1988: 52) and implied by the stacks of BRBs found in ovens at Eridu and Tell Brak) produced rapid pre-baking rising and significantly improved 'oven spring' (rising during baking, critically important for heavier flours) compared with a 'control' cold BRB, as well as speedier baking.

- BRB wall thickness was critical for bread volume: bread in a specially-made half-thickness BRB rose less well.

- The heavy temper in BRBs appears not to be critical for bread volume: bread in a specially-made untempered BRB rose equally well. Temper may be included for potterymanufacturing reasons: see Table 2, which relates particular features of the BRB to their manufacturing and functional advantages.

- Baking bread in an unfired BRB was successful, opening the question of why BRBs were fired: for durability, perhaps?

\section{Some suggested explanations for the varying scale of BRB deposits found}

At the height of Uruk activity, spectacularly large stacks or deposits of BRBs have been found over time at many key sites (Table 3). These BRBs were often apparently discarded intact, 


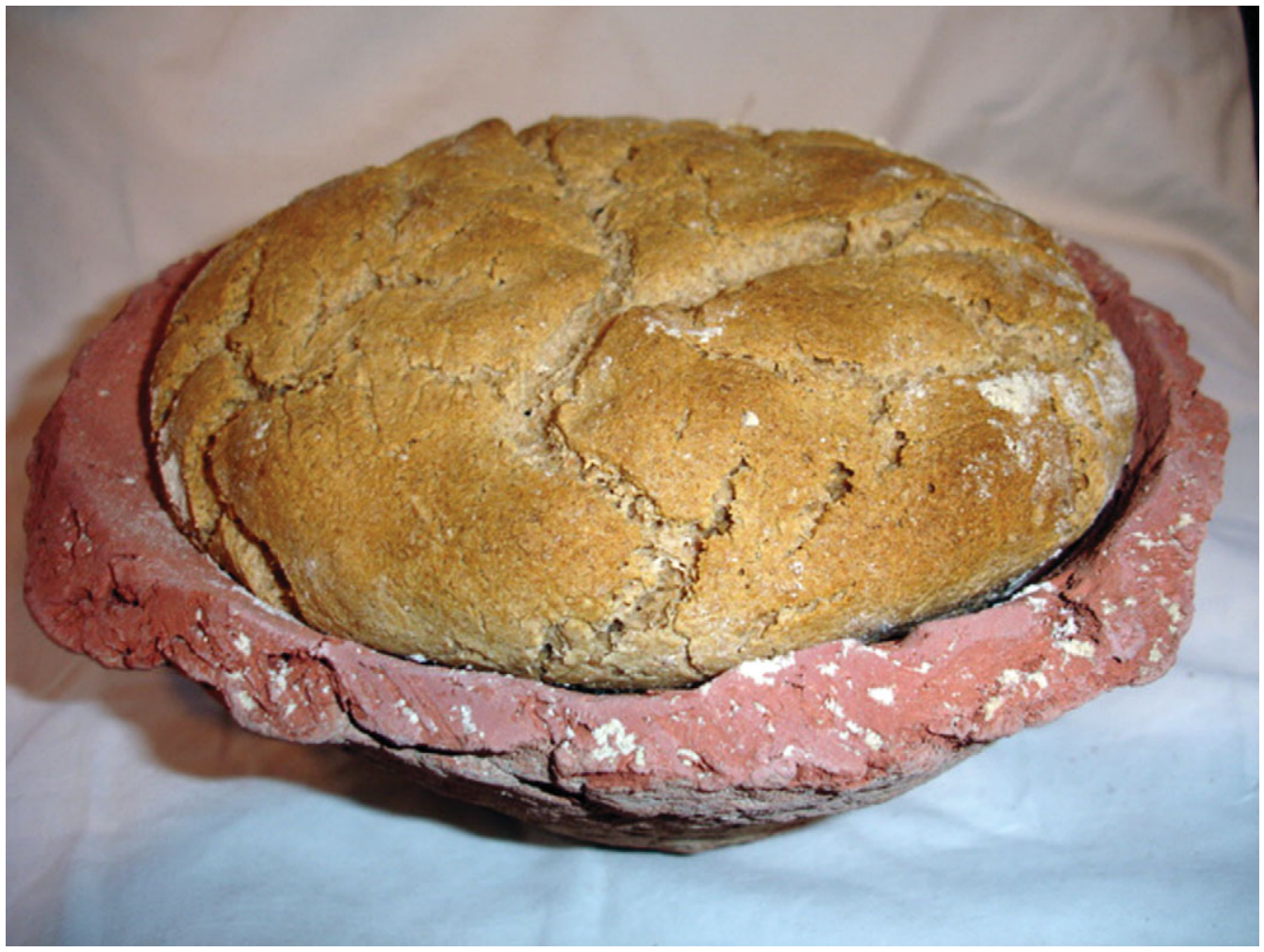

Figure 2. Bread baked in a replica BRB.

without recycling. One suite of possible explanations relates to the manufacturing process and to the BRB's low production cost: if BRBs were made in large batches when labour and raw materials were available, as with the seasonal pottery workshops mentioned in Ur III texts (Gaimster \& Freestone 1997: 15), this would help to explain the stashes of BRBs found. If, then, the anticipated demand did not materialise due to changed circumstances, the stacks might be dumped unused: BRBs would not be worth curation, being too cheap, heavy and fragile to transport.

A further set of explanations might apply if BRBs were indeed for central bread-baking. The leavened dough may be left to prove in the vessel for a period before cooking, so for efficient mass-production of bread, a large number of BRBs would be used at a time. If the numbers of consumers being supplied reduced, or if operations moved to a new location, or after one-off banquets, the excess BRBs would be stacked for storage or discarded.

At the other end of the scale, as archaeological emphasis moves away from urban centres and central Mesopotamia, less concentrated BRB finds are increasingly made, such as at Arslantepe, Çatal Hüyük in the Hatay (very late), Hama, Sakçe Gözü, Tell Açana, Tell Brak (early levels), Tell Judaidah (very late), Tell Mohammed 'Arab, Tell Qarqar and Tepe Yahya (Beale 1978: 300, 306; McAdam \& Mynors 1988: 49; Tomita 1988: 199; Frangipane 2001: 327; Schwartz 2001: 242, 264) and a growing number of Iranian plateau sites (Potts 2009: 5). The assumption that the BRB system was designed to deal with large-scale feeding of workers does not fit well with the earliest Uruk indications in the wider reaches of 
Mesopotamian influence as these often comprise only a few BRB sherds, sometimes well before the appearance of other Uruk cultural indications. Likewise such an assumption does not accord well with the decline in concentration, as opposed to the sudden absence from the record, of BRBs as the Uruk period drew to a close (Nicholas 1987: 68).

Even if possible specialist or secondary functions are taken into account, I argue that the new-found, richly-evidenced, chronological and geographical distribution of BRBs might better match the probable presence and number of administrative (or perhaps merchant or craft) individuals. Table 3 indicates a noticeably common association of large BRB concentrations with administrative buildings and artefacts. At the end of the Uruk period, many administrators would have been laid off and the system would no longer have supplied them with special bread. Future studies might address the possibility that some bread was still made in the persisting 'flowerpots', which lacked the prestige value of the now defunct 'BRB bread' shape.

\section{The case for prestige bread}

Fermentation technology was well-established by the Uruk period, but leavened bread in containers is a very elaborate technique for domestic bread (Samuel 2000: 567); and, as discussed earlier, wheat was an expensive ingredient. The sudden explosion of breadmoulds may point towards centralised production and distribution, with bakeries sited in 'backyard' areas near administrative or commercial buildings and supplying a daily staple to administrators. Wright (2001: 132) points out that social status attached to the eating of certain meats and grain preparations has not been addressed well for the fourth millennium: leavened wheat container-bread may well have been a delicacy then. I suggest that the findspots and distribution pattern, as well as the attention apparently paid to producing this bread, might better suit prestige bread manufacture for the new large administrative cadre recruited and trained to deal with the explosion of bureaucratic control apparent in the Uruk period. This urban specialist group, unable to grow their own food, might take to a new, distinctive, tasty staple such as leavened container-made bread as part of their differentiating 'salary', which then became part of their cultural identity.

I suggest, with Sherratt (2006), that what then moved out from Uruk to other regions was 'a model of culturally situated dietary practice' involving 'accounting systems, beer and leavened bread'. This 'package' not only provided familiar food and drink but also allowed participators (local elite and expatriate Uruk administrators) to signal their association with the Uruk 'brand', either in daily life or at festivities. Dual use of distinctive high-quality bread for both the daily rewarding of administrators and the ceremonial entertaining of bureaucrats, in addition to adoption by Urukised local emulators regionally (Potts 2009: 14), might assist in explaining the range of BRB quantities found.

\section{Conclusions}

The two pivotal characteristics of BRBs are wall thickness (the essential differentiating factor for bread-moulds (Jacquet-Gordon 1981: 23; Lehner 1995: 10)) and production-line capabilities. Recognition of the $\mathrm{BRB}$ as an engineered tool, designed to maximise ceramic 
and food production-line efficiency and not exposed to the consumer as a serving vessel, frees it from the conclusion that such a hideous vessel could only provide food for peasants. Bread-moulds, unlike serving vessels, are stacked not where the food is eaten but where the food is made. The technological beauty of the BRB is in its concept, not in its execution.

The study of mass-produced ceramics in fourth- and third-millennium Mesopotamia (Table 1) has been significantly biased by the twin assumptions that BRBs were for workers' rations and that this therefore applied to all mass-produced bowls. Whilst the form and features of BRBs do vary noticeably, I argue that they do so within an overall fit-for-purpose similarity, with the variations largely concerning non-critical features rather than strategic components which cannot be modified without jeopardizing the entire chain' (Van der Leeuw 1993: 240). What differentiates the BRB, as signalled by its pivotal physical characteristics, and what forms an important factor in the BRB's success, is its neat dual achievement of function (efficiently producing leavened bread) and need (production-line manufacture). BRB manufacture, I suggest, was largely a de-skilled process based on quantity rather than quality of workers and using a production-line approach. What has puzzled many commentators is why such creative attention has been paid to evolving a conceptually new system for producing such a banal item. The solution can only be reached if the BRB is divorced from the entire body of contemporary serving vessels and recognised as an active utensil, not a passive container, whose pivotal characteristics enable another large-scale rapid-throughput operation - bread-baking - to be carried out.

BRB distribution patterns do indeed reinforce the well-established view of the flowering of the first bureaucratic society, and 'BRB bread' may well have evolved initially as an urban product, but I suggest that its development as a prestige cultural indicator led to its growing presence in the rural and distant regions upon which the original urban core relied. We have here a rare opportunity to spot a particular food-form as an identifier or prestige indicator, in a culture in which many more archaeologically-visible social differentiators appear to have been suppressed.

\section{Acknowledgements}

My warmest thanks to David Wengrow, Bill Sillar, Henry Wright, Joan Oates, the late Andrew Sherratt (from whose unpublished article on BRBs Sue Sherratt has kindly allowed me to quote), Delwen Samuel and professional bakers Kurt Anderson and Liz Weisberg, for their assistance and encouragement towards the UCL MA dissertation from which this paper was developed.

\section{References}

ADAms, R.M. 1972. The Uruk countryside. Chicago (IL): University of Chicago Press.

AlgAZE, G. 2001. Initial social complexity in south-west Asia: the Mesopotamian advantage. Current Anthropology 42(2): 199-233.

BADLER, V. 1995. Winemaking, distribution and consumption at proto-historic Godin Tepe, Iran, in P.E. McGovern, S.J. Fleming \& S.H. Katz (ed.) The origins and ancient history of wine: 45-56.

Amsterdam: Gordon \& Breach.
BALFET, H. 1980. A propos du métier d'argile: exemple de dialogue entre ethnologie et archéologie, in M.T. Barrelet (ed.) L'archéologie de l'Iraq: du début de l'époque néolithique à 333 avant notre ère: perspectives et limites de l'interprétation anthropologique des documents, Paris 13-15 Juin, 1978: 71-84. Paris: Centre National de la Recherche Scientifique.

BAUMGÄRTEL, E.J. 1947. The cultures of prehistoric Egypt, volume I. London: Oxford University Press.

BEALE, T.W. 1978. Bevelled-rim bowls and their implications for change and economic organization in the later fourth millennium. Journal of Near Eastern Studies 37: 289-313. 


\section{Jill Goulder}

BuCCELlati, G. 1999. Urkesh and the question of early human urbanism, in M. Hudson \& B.A. Levine (ed.) Urbanization and land ownership: 229-50. Cambridge (MA): Peabody Museum of Archaeology and Ethnology, Harvard University.

Charvát, P. 2002. Mesopotamia before history. London: Routledge.

Chazan, M. \& M. LeHner. 1990. An ancient analogy: pot baked bread in ancient Egypt and Mesopotamia. Paléorient 16(2): 21-35.

Collins, P. 2000. The Uruk phenomenon: the role of social ideology in the expansion of the Uruk culture during the fourth millennium BC (British Archaeological Reports International Series 900). Oxford: Archaeopress.

Crawford, H. 2004. Sumer and the Sumerians. Second edition. Cambridge: Cambridge University Press.

Delougaz, P. 1952. Pottery from the Diyala region. Chicago (IL): University of Chicago Press.

Delougaz, P. \& H.J. Kantor. 1996. Chogha Mish. Chicago (IL): University of Chicago Press.

FOREST, J.-D. 1987. Les bevelled rim bowls: nouvelle tentative d'interprétation. Akkadica 53: 1-24.

Frangipane, M. 2001. Centralization processes in Greater Mesopotamia: Uruk 'expansion' as the climax of systemic interactions among areas of the Greater Mesopotamian region, in M.S. Rothman (ed.) Uruk Mesopotamia and its neighbors: cross-cultural interactions in the era of state formation: 307-48. Santa Fe (NM): School of American Research Press.

-2002. Non-Uruk developments and Uruk-linked features on the northern borders of Greater Mesopotamia, in J.N. Postgate (ed.) Artefacts of complexity: tracking the Uruk in the Near East: 123-48. Warminster: British School of Archaeology in Iraq.

Gaimster, D. \& I. Freestone. 1997. Introduction, in I. Freestone \& D. Gaimster (ed.) Pottery in the making: world ceramic traditions: 9-19. London: British Museum Press.

JACQUET-GORDON, H. 1981. A tentative typology of Egyptian bread-moulds, in D. Arnold (ed.) Studien zur Altägyptischen Keramik: 11-24. Mainz: Philipp von Zabern.

JofFe, A.H. 1998. Alcohol and social complexity in ancient Western Asia. Current Anthropology 39(3): 297-322.

JOHNSON, G.A. 1973. Local exchange and early state development in south-western Iran. Ann Arbor (MI): Museum of Anthropology, University of Michigan.

-1976. Early state organization in south-western Iran: preliminary field report, in F. Bagherzadeh (ed.) IVth symposium on Iran: 190-223. Tehran: Iranian Centre for Archaeological Research.
KalsbeeK, J. 1980. La céramique de série du Djebel 'Aruda (à l'époque d'Uruk). Akkadica 20: 1-11.

KeMP, B.J. 2006. Ancient Egypt: anatomy of a civilisation. London: Routledge.

LE Brun, A. 1980. Les écuelles grossières: état de la question, in M.-T. Barrelet (ed.) L'archéologie de l'Iraq: du début de l'époque néolithique à 333 avant notre ère: perspectives et limites de l'interprétation anthropologique des documents, Paris 13-15 Juin, 1978: 59-70. Paris: Centre National de la Recherche Scientifique.

Lehner, M. 1995. The Giza Plateau mapping project: 1993-4 annual report. Available at: http://oi.uchicago.edu/research/pubs/ar/9394/giza.html, accessed 25 November 2008.

MaHIAS, M.-C. 1993. Pottery techniques in India: technical variants and social choice, in P. Lemonnier (ed.) Technological choices: transformation in material cultures since the Neolithic: 157-80. London: Routledge.

MALLOWAN, M.E.L. 1933. The prehistoric sondage of Nineveh 1931-2, in R. Campbell-Thompson \& M.E.L. Mallowan (ed.) The British Museum excavations at Nineveh 1931-2 (University of Liverpool Annals of Archaeology and Anthropology 20, 2): 127-86. Liverpool: Liverpool University Press.

McAdAM, E. \& H.S. MynORS. 1988. Tell Rubeidheh: pottery from the Uruk mound, in R.G. Killick (ed.) Tell Rubeidheh: an Uruk village in the Jebel Hamrin: 39-76. Warminster: Aris \& Phillips/British School of Archaeology in Iraq and the Directorate of Antiquities.

Millard, A.R. 1988. The bevelled-rim bowls: their purpose and significance. Iraq 50: 49-58.

Miller, A. 1981. Straw tempered ware, in H.T. Wright (ed.) An early town on the Deh Luran Plain: excavations at Tepe Farukhabad: 126-9. Ann Arbor (MI): Museum of Anthropology, University of Michigan.

NiCHOLAS, I.M. 1987. The function of bevelled-rim bowls: a case study at the TUV mound, Tal-e Malyan, Iran. Paléorient 13(2): 61-72.

NisSEN, H.J. 1988. The early history of the ancient Near East, 9000-2000 BC. Chicago (IL): University of Chicago Press.

OATES, D. \& J. OATES. 1976. Early irrigation agriculture in Mesopotamia, in G. de Sieveking, I.H. Longworth \& K.E. Wilson (ed.) Problems in economic and social Archaeology: 109-35. London: Duckworth.

-1993. Excavations at Tell Brak 1992-3. Iraq 55: 155-200. 
Peltenburg, E., D. Bolger, S. Campbell, M.A. Murray \& R. TipPING. 1996. Jerablus-Tahtani, Syria, 1995: preliminary report. Levant 28: 1-26.

Pollock, S., M. Pope \& C. Coursey. 1996. Household production at the Uruk mound, Abu Salabikh, Iraq. American Journal of Archaeology 100(4): 683-98.

Pollock, S. \& C. COURSEY. 1996. Hacınebi Uruk pottery: preliminary report. American Journal of Archaeology 100(2): 233-9.

POTTS, D.T. 1984. On salt and salt gathering in ancient Mesopotamia. Journal of the Economic and Social History of the Orient 27(3): 225-71.

-1997. Mesopotamian civilization: the material foundations. London: Athlone Press.

-2009. Bevel-rim bowls and bakeries: evidence and explanations from Iran and the Indo-Iranian borderlands. Journal of Cuneiform Studies 61: 1-23.

RICE, P.M. 1987. Pottery analysis: a sourcebook. Chicago (IL): University of Chicago Press.

Rothman, M.S. 2002. Tepe Gawra: chronology and socio-economic change, in J.N. Postgate (ed.) Artefacts of complexity: tracking the Uruk in the Near East: 49-69. Warminster: British School of Archaeology in Iraq.

RYE, O.S. 1981. Pottery technology: principles and reconstruction. Washington (DC): Taraxacum.

SAMUEL, D. 2000. Brewing and baking, in P.T. Nicholson \& I. Shaw (ed.) Ancient Egyptian materials and technology: 537-76. Cambridge: Cambridge University Press.

Schmandt-Besserat, D. 1992. Before writing. Austin (TX): University of Texas Press.

SCHMIDT, K. 1982. Zur Verwendung der mesopotamischen 'Glockentopfe'. Archäologisches Korrespondenzblatt 12: 317-19.

SCHWARTZ, G.M. 2001. Syria and the Uruk expansion, in M.S. Rothman (ed.) Uruk Mesopotamia and its neighbors: cross-cultural interactions in the era of state formation: 233-64. Santa Fe (NM): School of American Research Press.

Sherratt, A. 2006. Bread, butter and beer: dietary change and urbanisation in early Mesopotamia and surrounding areas (6000-3000 BC). Unpublished manuscript.

SimPSON, ST. J. 1997. Early urban ceramic industries in Mesopotamia, in I. Freestone \& D. Gaimster (ed.) Pottery in the making: world ceramic traditions: 50-55. London: British Museum Press.

SteIN, G.J. \& A. MisiR. 1996. The fourth-millennium occupation of Hacinebi. American Journal of Archaeology 100(2): 206-22.
Stephen, F.M.K. \& E. Peltenburg. 2002. Scientific analyses of Uruk ceramics from Jerablus Tahtani and other Middle-Upper Euphrates sites, in J.N. Postgate (ed.) Artefacts of complexity: tracking the Uruk in the Near East: 173-81. Warminster: British School of Archaeology in Iraq.

Strommenger, E. 1980. Habuba Kabira: eine Stadt vor 5000 Jahren. Ausgrabungen der Deutschen Orient-Gesellschaft am Euphrat in Habuba Kabira, Syrien. Mainz: Philipp von Zabern.

SÜRENHAGEN, D. 1974/5. Untersuchungen zur Keramikproduktion innerhalb der spät-Urukzeitlichen Siedlung Habuba Kabira-Süd in Nord-Syrien. Acta Praehistorica et Archaeologica 5/6: 43-164.

TOMITA, T. 1998. Late Chalcolithic chronology in Syria and Northern Mesopotamia, in A. Tsuneki \& Y. Miyake (ed.) Excavations at Tell Umm Qseir in middle Khabur Valley, north Syria: report of the 1996 season: 197-201. Tsukuba, Japan: Department of Archaeology, Institute of History and Anthropology, University of Tsukuba.

VAN DER LEEUW, S. 1993. Giving the potter a choice: conceptual aspects of pottery techniques, in $\mathrm{P}$. Lemonnier (ed.) Technological choices: transformation in material cultures since the Neolithic: 238-88. London: Routledge.

Wright, H.T. 1981. An early town on the Deh Luran Plain: excavations at Tepe Farukhabad. Ann Arbor (MI): Museum of Anthropology, University of Michigan.

-1998. Uruk states in south-western Iran, in G.M. Feinman \& J. Marcus (ed.) Archaic states: 172-97. Santa Fe (NM): School of American Research Press.

- 2001. Cultural action in the Uruk world, in M.S. Rothman (ed.) Uruk Mesopotamia and its neighbors: cross-cultural interactions in the era of state formation: 123-48. Santa Fe (NM): School of American Research Press.

Wright, H.T. \& E.S.A. RuPLEY. 2001. Calibrated radiocarbon age determinations of Uruk-related assemblages, in M.S. Rothman (ed.) Uruk Mesopotamia and its neighbors: cross-cultural interactions in the era of state formation: 85-122. Santa Fe (NM): School of American Research Press.

Wright, H.T., N.F. MiLler \& R. RedDing. 1980. Time and process in an Uruk rural centre, in M.-T. Barrelet (ed.) L'Archéologie de l'Iraq: du début de l'époque néolithique à 333 avant notre ère: perspectives et limites de l'interprétation anthropologique des documents, Paris 13-15 Juin, 1978 : 265-84. Paris: Centre National de la Recherche Scientifique. 